\title{
Pulmonar recruitment in acute respiratory distress syndrome. What is the best strategy?
}

\section{Recrutamento pulmonar na síndrome do desconforto respiratório agudo. Qual a melhor estratégia?}

Cíntia lourenço Santos ${ }^{1}$; Cynthia dos Santos Samary2; Pedro laurindo Fiorio Júnior 3 ; Bruna lourenço Santos ${ }^{4}$; Alberto SCHANaider, TCBC-RJ

\author{
A
}

\begin{abstract}
Supporting patients with acute respiratory distress syndrome (ARDS), using a protective mechanical ventilation strategy characterized by low tidal volume and limitation of positive end-expiratory pressure (PEEP) is a standard practice in the intensive care unit. However, these strategies can promote lung de-recruitment, leading to the cyclic closing and reopening of collapsed alveoli and small airways. Recruitment maneuvers (RM) can be used to augment other methods, like positive endexpiratory pressure and positioning, to improve aerated lung volume. Clinical practice varies widely, and the optimal method and patient selection for recruitment maneuvers have not been determined, considerable uncertainty remaining regarding the appropriateness of RM. This review aims to discuss recent findings about the available types of RM, and compare the effectiveness, indications and adverse effects among them, as well as their impact on morbidity and mortality in ARDS patients. Recent developments include experimental and clinical evidence that a stepwise extended recruitment maneuver may cause an improvement in aerated lung volume and decrease the biological impact seen with the traditionally used sustained inflation, with less adverse effects. Prone positioning can reduce mortality in severe ARDS patients and may be an useful adjunct to recruitment maneuvers and advanced ventilatory strategies, such noisy ventilation and BIVENT, which have been useful in providing lung recruitment.
\end{abstract}

Key words: Valsava Maneuver. Positive-Pressure Respiration. Respiratory Distress Syndrome, Adult. Respiration, Artificial. Prone Position.

\section{INTRODUCTION}

$T$ he acute respiratory distress syndrome (ARDS) is a worldwide public health problem, occurring even today, with high rates of mortality. Despite the many strategies proposed so far, the only isolated therapy that effectively changed the prognosis of patients, with a significant reduction in morbidity and mortality rates, was the protective ventilatory strategy, characterized by the use of low tidal volume $(4-8 \mathrm{ml} / \mathrm{kg})^{1.2}$. However, this strategy can facilitate alveolar de-recruitment and promote the cyclic opening and closing of alveoli, which is considered one of the mechanisms of promotion and exacerbation of lung injury $^{3}$. In this context, various strategies, ranging from ventilation modes to specific maneuvers, have been proposed to minimize alveolar collapse and promote a more homogeneous ventilation distribution. The use of recruitment maneuvers (RM) aims to reopen collapsed alveolar, units based on a transient increase in transpulmonary pressure $\left(\mathrm{P}_{\mathrm{TP}}\right)$ during mechanical ventilation ${ }^{4,5}$.

Nevertheless, the RM can also exacerbate the damage to pulmonary epithelial ${ }^{6}$ and endothelial ${ }^{7}$ cells, increasing the alveolar-capillary permeability, which can exacerbate the syndrome ${ }^{8}$.

The objective of this study is to discuss the main strategies used to promote alveolar recruitment in patients with ARDS, as well as its benefits, indications and limitations. Finally, it aims to apply the concepts to clinical practice, in patients with ARDS.

\section{METHODS}

We conducted a wide survey in the database of "National Library of Medicine" / Pubmed using the following key words and descriptors, alone or in combination:

1. Experimental Surgery Center, Faculty of Medicine, Universidade Federal do Rio de Janeiro, Rio de Janeiro, Rio de Janeiro State - RJ, Brazil; 2. Pulmonary Research Laboratory, Carlos Chagas Filho Institute of Biophysics, Universidade Federal do Rio de Janeiro; 3 . Universidade Federal de Lavras, Lavras, Minas Gerais State - MG, Brazil; 4. Universidade Estacio de Sá, Rio de Janeiro; 5. Department of Surgery, Faculty of Medicine, Universidade Federal do Rio de Janeiro. 
"Mechanical ventilation", "Acute respiratory Distress Syndrome", "Recruitment maneuvers" "Prone positioning," "Noisy ventilation", "positive end expiratory pressure." We selected the most relevant articles, as well as the classic works on mechanical ventilation in acute respiratory distress syndrome. We included in the selection clinical and experimental original articles, multicenter studies and metaanalyzes. We tried to make a critical analysis of the current data available regarding the use of recruitment maneuvers in ARDS, as well as its benefits, indications and limitations.

\section{Lung recruitment}

The recruitment aims to promote reopening of collapsed alveoli. Therefore, there can be used several mechanical ventilation strategies, patient positioning and specific recruitment maneuvers or association of one or more of these mechanisms.

\section{Prone positioning}

The prone position is a relatively simple and safe method for improved oxygenation, which can be regarded as a recruitment maneuver itself, improving gas exchange, promoting alveolar recruitment, without providing areas of hyperinflation ${ }^{2,9}$.

When patients are placed in the prone position, the chest wall compliance decreases, and the $P_{T P}$ is redistributed from dorsal to ventral and, as a consequence, there is a recruitment of pulmonary dorsal regions, which directly reflects the improvement in patient's oxygenation ${ }^{10-}$ 12. By promoting a more balanced ventilation associated with recruitment, the prone position also results in a better distribution of blood flow ${ }^{13}$, preventing its inappropriate redirection from hyperinflated areas to the collapsed ones in response to increased average airway pressure and positive end-expiratory pressure (PEEP) ${ }^{14,15}$.

In addition to direct effects, studies show that the ventilation in prone protects from, or at least slows the development of, injuries associated with mechanical ventilation $^{16}$. Therefore, to provide a more homogeneous distribution of the $\mathrm{P}_{\text {TP }}$ gradient, there is a redirection of ventilation, making it more uniform ${ }^{17}$, which helps to establish and maintain lung recruitment in response to PEEP18, as well as reducing alveolar hyperinflation ${ }^{19}$.

The benefits of the prone position to ARDS patients during mechanical ventilation have been proven by several studies. However, the reduction of the mortality rate was proven recently in the PROSEVA study, published in $2013^{20}$. The multicenter data established that this position is strongly indicated in patients with severe ARDS20, which, according to the latest definition of Berlin (2012), includes patients with $\mathrm{PaO}_{2} / \mathrm{FiO}_{2}$ ratio of less than $100 \mathrm{mmHg}^{21}$. Moreover, these data clearly show that there is no advantage of this positioning in relation to increased survival in mild ARDS $\left(\mathrm{PaO}_{2} / \mathrm{FiO}_{2} \text { from } 200 \text { to } 300 \mathrm{mmHg}\right)^{20}$.

Regarding moderate ARDS, the data are still controversial. By making a more detailed analysis of recently published large studies $20,22,23$, it can be suggested that prone positioning should be considered for patients with $\mathrm{PaO}_{2}$ / $\mathrm{FiO}_{2}$, below $150 \mathrm{mmHg}$, when they are under a PEEP than higher $5 \mathrm{cmH}_{2} \mathrm{O}$ and $\mathrm{FiO}_{2}$ the greater than 0.6.

Another point to be considered is at what ARDS stage should the patient be put in the prone position. Despite promoting effective improvement in oxygenation after many days of the onset of the syndrome, the data on survival suggest that the best response is related to the early positioning of the patient in prone ${ }^{20}$. This fact can be explained by factors for which the prone position has its most evident benefit, such as edema, reversible alveolar collapse areas and absence of major structural lung changes. In addition, prone applied early is more effective at reducing the risk of ventilator-associated lung injury (VALI) when compared with more advanced stages, since in these the damage has already been established ${ }^{20.23}$.

Importantly, due to prone positioning promoting significant improvement in oxygenation, it eventually reduces the need for other ventilatory interventions that may be iatrogenic. Moreover, it may allow reducing the fraction of inspired oxygen $\left(\mathrm{FiO}_{2}\right)$ and airway pressure, also reducing the need for fluid infusion and, thus, the risk of additional injury to the mechanically stressed membranes and of cardiac overload.

\section{Ventilation strategies}

Some non-traditional ventilation modes have recently been suggested to promote lung recruitment. The biphasic positive airway pressure (BIVENT) mode allows ventilation with two levels of CPAP (Continuous Positive Airway Pressure) - high pressure (Phigh) and low pressure (Plow) and, when associated with PSV (Pressure Support Ventilation), results in increase of the mean airway pressure and hence, increased $\mathrm{P}_{\mathrm{TP}}{ }^{24}$. Thus, it facilitates the opening of the previously collapsed airways by means of the installed pressure gradient. In addition, through the help of spontaneous breathing with diaphragmatic contraction, there is an increased ventilation of the lower posterior areas of the lungs, minimizing the airway pressure ${ }^{24,25}$

The "variable ventilation", characterized by changes in tidal volume and respiratory rate, cycle by cycle, simulates the breath of normal individuals. Experimental studies show that it leads to improved oxygenation and respiratory mechanics and the reduction of diffuse alveolar damage ${ }^{26-28}$. By generating different levels of volume within biological parameters, it reaches a critical opening pressure of the collapsed airways, followed by the opening the remaining airways with less opening pressure, leading to improvement in gas exchange and reduction of alveolar collapse $\mathrm{e}^{29,30}$.

Since these structures have different time constants in different regions of the lung, the mechanical ventilation with different pressure patterns and inspiratory times may be useful to recruit and stabilize the lungs when compared to regular respiratory patterns. 


\section{Recruitment maneuvers}

The most used RM is sustained inflation, characterized by an abrupt increase in airway pressure (40 $\mathrm{cm} \mathrm{H}_{2} \mathrm{O}$ ) over a specific time (within 60 seconds) ${ }^{31}$. The sustained inflation is effective in reducing pulmonary atelectasis $^{32}$, improving oxygenation ${ }^{33}$ and respiratory mechanics ${ }^{33}$, preventing alveolar de-recruitment.

However, this maneuver requires high inspiratory flow and, when applied to an inhomogeneous lung parenchyma, may bring deleterious effects, predisposing to alveolar deformation during pulmonary distress, contributing to VALI, with bacterial ${ }^{34}$ and cytokines translocation into the systemic circulation ${ }^{35}$. Other studies have shown the benefit of this maneuver has limited duration, associated with high hemodynamic instability, increased risk of barotrauma / volutrauma ${ }^{36}$, increased intracranial pressure ${ }^{37}$, and reduced clearance of alveolar fluid $^{8}$, resulting in poor oxygenation and ${ }^{38}$ serious clinical consequences ${ }^{36}$

A recruitment maneuver considered "more physiological" is setting longer breath cycles during mechanical ventilation with a constant tidal volume, mimicking the sigh observed during normal breathing in healthy individuals. It can be obtained from a sequence of independent or consecutive breaths to reach a high plateau pressure in a volume- or pressure-controlled ventilation mode or by the periodic PEEP increase for a few cycles ${ }^{4}$. The sigh counterbalances the alveolar collapse tendency during ventilation with low tidal volumes, thus improving the respiratory function in patients with acute respiratory distress syndrome (ARDS), both in the controlled $(P C V)^{4}$ and in the support (PSV) ${ }^{39}$ ventilation modes. In the latter, experimental models suggest that the sigh reduces alveolar collapse and helps protect the lung from VALI ${ }^{40}$.
Gradual recruitment (step) maneuvers have been quite effective when applied to heterogeneous lung parenchyma, with different time constants for small airways opening, thus promoting lower biological impact when compared with the abrupt pressure increase ${ }^{41}$. The step can be obtained through a slow and gradual increase of PEEP or also by increasing inspiratory driving pressure up to a threshold pressure, in general $40 \mathrm{~cm} \mathrm{H}_{2} \mathrm{O}$. Furthermore, in step there are smaller hemodynamic effects, since the average pressure achieved during this maneuver is lower ${ }^{41}$.

\section{FINAL CONSIDERATIONS}

Which patients have a better response to recruitment maneuvers?

Recruitment maneuvers (RM) are not without risks. To reduce the number of patients unnecessarily exposed can prevent potential complications. Importantly, to date no multicenter study demonstrated the superiority of RM, associated with protective strategy, in terms of survival. Thus, their use should always be cautious and some points should be observed. The earlier or exudative phase of acute respiratory distress syndrome (ARDS), the better the chance of RM success compared with a later or fibrotic phase ${ }^{42}$. Patients with extrapulmonary etiology of ARDS have better response to recruitment ${ }^{41.43}$. Therefore, those with diffuse changes on imaging studies have better chance of RM success than those with focal changes ${ }^{3}$. Patients with severe ARDS respond better to $\mathrm{RM}^{19}$ and the high respiratory system elastance is associated with better response to recruitment in clinical trials ${ }^{19}$. On the other hand, when there is low thoracic wall elastance, the response to RM will be worse ${ }^{42}$.

\section{RE S U M O}

O suporte a pacientes com a Síndrome do Desconforto Respiratório Agudo (SDRA), realizado com baixos volumes correntes e limite da pressão positiva ao final da expiração (PEEP), é o padrão ouro no tratamento de pacientes internados em Unidades de Terapia Intensiva. No entanto, essas estratégias podem promover o desrecrutamento pulmonar levando ao fechamento e reabertura cíclicos de alvéolos colapsados e de pequenas vias aéreas. As manobras de recrutamento (MR) podem ser usadas em conjunto a outros métodos, como a PEEP e posicionamento dos pacientes, para promover melhora no volume pulmonar aerado. Diversos métodos são utilizados na prática clínica, mas o mais adequado e a seleção de qual paciente se beneficiaria de MR ainda não estão estabelecidos. Além disso, ainda permanecem consideráveis incertezas em relação a adequação da MR. Esta revisão objetiva discutir as últimas descobertas acerca das MR existentes e compará-las no que tange a suas eficácias, indicações e complicações. Descobertas recentes incluem evidencias clínicas e experimentais que a manobra de recrutamento em "STEP" pode promover uma melhora do volume pulmonar aerado e reduzir o impacto biológico observado na insulflação sustentada tradicionalmente usada. O posicionamento em prona pode reduzir a mortalidade em pacientes com SDRA grave e ser um coadjuvante nas manobras de recrutamento e estratégias ventilatórias avançadas como a ventilação variável e o BIVENT tem se mostrado úteis em proporcionar recrutamento pulmonar.

Descritores: Manobras de Valsava. Respiração com Pressão Positiva, Síndrome do Desconforto Respiratório do Adulto. Respiração Artificial. Decúbito Ventral. 


\section{REFERENCES}

1. Amato MB, Barbas CS, Medeiros DM, Magaldi RB, Schettino GP, Lorenzi-Filho $G$,et al. Effect of a protectiveventilation strategy on mortality in the acute respiratory distress syndrome. N Engl J Med. 1998;338(6):347-54.

2. Tonelli AR, Zein J, Adams J, loannidis JP. Effects of interventions on survival in acute respiratory distress syndrome: an umbrella review of 159 published randomized trials and 29 meta-analyses. Intensive Care Med. 2014;40(6):769-87.

3. Pelosi P, Goldner M, McKibben A, Adams A, Eccher G, Caironi P, et al. Recruitment and derecruitment during acute respiratory failure: an experimental study. Am J Respir Crit Care Med. 2001;164(1):122-30.

4. Pelosi P, Cadringher P, Bottino N, Panigada M, Carrieri F, Riva E, et al.Sigh in acute respiratory distress syndrome. Am J Respir Crit Care Med. 1999;159(3):872-80.

5. Tremblay LN, Slutsky AS. Ventilator-induced lung injury: from the bench to the bedside. Intensive Care Med. 2006;32(1):24-33.

6. Silva PL, Moraes L, Santos RS, Samary C, Ornellas DS, MaronGutierrez T, et al. Impact of pressure profile and duration of recruitment maneuvers on morphofunctional and biochemical variables in experimental lung injury. Crit Care Med. 2011:39(5):1074-81.

7. Silva PL, Cruz FF, Fujisaki LC, Oliveira GP, Samary CS, Ornellas DS, et al. Hypervolemia induces and potentiates lung damage after recruitment maneuver in a model of sepsis-induced acute lung injury. Crit Care 2010;14(3):R114.

8. Constantin JM, Cayot-Constantin S, Roszyk L, Futier E, Sapin $V$, Dastugue $B$, et al. Response to recruitment maneuver influences net alveolar fluid clearance in acute respiratory distress syndrome. Anesthesiology. 2007;106(5):944-51.

9. Cornejo RA, Díaz JC, Tobar EA, Bruhn AR, Ramos CA, González $R A$, et al. Effects of prone positioning on lung protection in patients with acute respiratory distress syndrome. Am J Respir Crit Care Med. 2013;188(4):440-8.

10. Gattinoni L, Pelosi P, Vitale G, Pesenti A, D'Andrea L, Mascheroni D. Body position changes redistribute lung computed-tomographic density in patients with acute respiratory failure. Anesthesiology. 1991:74(1):15-23.

11. Gattinoni L, Pesenti A, Carlesso E. Body position changes redistribute lung cumputed-tomographic density in patients with acute respiratory failure: impact and clinical fallout though the following 20 years. Intensive Care Med. 2013;39(11):1909-15.

12. Wilson JG, Matthay MA. Mechanical ventilation in acute hypoxemic respiratory failure: a review of new strategies for the practicing hospitalist.J Hosp Med. 2014;9(7):469-75.

13. Petersson J, Ax M, Frey J, Sánchez-Crespo A, Lindahl SG, Mure M. Positive end-expiratory pressure redistributes regional blood flow and ventilation differently in supine and prone humans.Anesthesiology. 2010;113(6):1361-9.

14. Lamm WJ, Graham MM, Albert RK. Mechanism by which the prone position improves oxygenation in acute lung injury. Am J Respir Crit Care Med, 1994;150(1):184-93.

15. Richter T, Bellani G, Scott Harris R, Vidal Melo MF, Winkler $T$, Venegas JG, et al. Effect of prone position on regional shunt, aeration, and perfusion in experimental acute lung injury. Am J Respir Crit Care Med. 2005;172(4):480-7.

16. Slutsky AS, Ranieri VM. Ventilator-induced lung injury. N Engl J Med. 2013;369(22):2126-36. Erratum in: N Engl J Med. 2014;370(17):1668-9.

17. Mentzelopoulos SD, Roussos C, Zakynthinos SG. Prone position reduces lung stress and strain in severe acute respiratory distress syndrome. Eur Respir J. 2005;25(3):534-44.

18. Rival G, Patry C, Floret N, Navellou JC, Belle E, Capellier G. Prone position and recruitment manoeuvre: the combined effect improves oxygenation. Crit Care. 2011;15(3):R125.

19. Galiatsou E, Kostanti E, Svarna E, Kitsakos A, Koulouras $\mathrm{V}$, Efremidis SC, et al. Prone position augments recruitment and prevents alveolar overinflation in acute lung injury. Am J Respir Crit Care Med. 2006;174(2):187-97

20. Guérin C, Reignier J, Richard JC, Beuret P, Gacouin A, Boulain T, et al.Prone positioning in severe acute respiratory distress syndrome. N Engl J Med. 2013;368(23):2159-68.

21. ARDS Definition Task Force, Ranieri VM, Rubenfeld GD, Thompson $B T$, Ferguson ND, Caldwell E, et al. Acute respiratory distress syndrome: the BerlinDefinition. JAMA. 2012;307(23):2526-33.

22. Sud S, Friedrich JO, Taccone $P$, Polli F, Adhikari NK, Latini $R$, et al. Prone ventilation reduces mortality in patients with acute respiratory failure and severe hypoxemia: systematic review and meta-analysis. Intensive Care Med. 2010;36(4):585-99.

23. Lee JM, Bae W, Lee YJ, Cho YJ. The efficacy and safety of prone positional ventilation in acute respiratory distress syndrome: updated study-level metaanalysis of 11 randomized controlled trials. Crit Care Med. 2014;42(5):1252-62.

24. Saddy F, Moraes L, Santos CL, Oliveira GP, Cruz FF, Morales MM, et al. Biphasic positive airway pressure minimizes biological impact on lung tissue in mild acute lung injury independent of etiology. Crit Care. 2013;17(5):R228.

25. Saddy F, Oliveira GP, Garcia CS, Nardelli LM, Rzezinski AF, Ornellas $D S$, et al. Assisted ventilation modes reduce the expression of lung inflammatory and fibrogenic mediators in a model of mild acute lung injury. Intensive Care Med. 2010;36(8):1417-26.

26. Funk DJ, Graham MR, Girling LG, Thliveris JA, McManus BM, Walker EK, et al. A comparison of biologically variable ventilation to recruitment manoeuvres in a porcine model of acute lung injury. Respir Res. 2004;5:22.

27. Spieth PM, Carvalho AR, Pelosi P, Hoehn C, Meissner C, Kasper $M$, et al. Variable tidal volumes improve lung protective ventilation strategies in experimental lung injury. Am J Respir Crit Care Med. 2009;179(8):684-93.

28. Bellardine CL, Hoffman AM, Tsai L, Ingenito EP, Arold SP, Lutchen $K R$, et al. Comparison of variable and conventional ventilation in a sheep saline lavage lung injury model. Crit Care Med. 2006;34(2):439-45.

29. Suki B, Barabási AL, Hantos Z, Peták F, Stanley HE. Avalanches and power-law behaviour in lung inflation. Nature. 1994;368(6472):615-8.

30. Mutch WA, Harms S, Ruth Graham M, Kowalski SE, Girling LG, Lefevre GR. Biologically variable or naturally noisy mechanical ventilation recruits atelectatic lung. Am J Respir Crit Care Med. 2000;162(1):319-23

31. Fan E, Wilcox ME, Brower RG. Recruitment maneuvers for acute lung injury: a systematic review. Am J Respir Crit Care Med. 2008;178(11):1156-63

32. Farias LL, Faffe DS, Xisto DG, Santana MC, Lassance R, Prota $L F$, et al. Positive end-expiratory pressure prevents lung mechanical stress caused by recruitment/derecruitment. J Appl Physiol (1985). 2005:98(1):53-61.

33. Lapinsky SE, Aubin M, Mehta S, Boiteau P, Slutsky AS. Safety and efficacy of a sustained inflation for alveolar recruitment in adults with respiratory failure. Intensive Care Med. 1999;25(11):1297301.

34. Cakar N, Akinci O, Tugrul S, Ozcan PE, Esen F, Eraksoy $H$, et al. Recruitment maneuver: does it promote bacterial translocation? Crit Care Med. 2002;30(9):2103-6.

35. Halbertsma FJ, Vaneker M, Pickkers P, Neeleman C, Scheffer GJ, Hoeven van der JG. A single recruitment maneuver in ventilated critically ill children can translocate pulmonary cytokines into the circulation. J Crit Care. 2010;25(1):10-5.

36. Meade MO, Cook DJ, Griffith LE, Hand LE, Lapinsky SE, Stewart $T E$, et al. A study of the physiologic responses to a lung recruitment maneuver in acute lung injury and acute respiratory distress syndrome. Respir Care. 2008;53(11):1441-9.

37. Bein T, Kuhr LP, Bele S, Ploner F, Keyl C, Taeger K. Lung recruitment maneuver in patients with cerebral injury: effects on intracranial pressure and cerebral metabolism. Intensive Care Med. 2002;28(5):554-8 
38. Musch G, Harris RS, Vidal Melo MF, O'Neill KR, Layfield JD, Winkler $T$, et al. Mechanism by which a sustained inflation can worsen oxygenation in acute lung injury. Anesthesiology. 2004;100(5):32330 .

39. Patroniti N, Foti G, Cortinovis B, Maggioni E, Bigatello LM, Cereda $M$, et al. Sigh improves gas exchange and lung volume in patients with acute respiratory distress syndrome undergoing pressure support ventilation. Anesthesiology. 2002;96(4):788-94.

40. Moraes L, Santos CL, Santos RS, Cruz FF, Saddy F, Morales MM, et al. Effects of sigh during pressure control and pressure support ventilation in pulmonary and extrapulmonary mild acute lung injury. Crit Care. 2014;18(4):474.

41. Silva PL, Moraes L, Santos RS, Samary C, Ramos MB, Santos CL, et al. Recruitment maneuvers modulate epithelial and endothelial cell response according to acute lung injury etiology. Crit Care Med. 2013;41(10):e256-65.
42. Grasso S, Mascia L, Del Turco M, Malacarne P, Giunta F, Brochard $L$, et al. Effects of recruiting maneuvers in patients with acute respiratory distress syndrome ventilated with protective ventilatory strategy. Anesthesiology. 2002;96(4):795-802.

43. Foti G, Cereda M, Sparacino ME, De Marchi L, Villa F, Pesenti A. Effects of periodic lung recruitment maneuvers on gas exchange and respiratory mechanics in mechanically ventilated acute respiratory distress syndrome (ARDS) patients. Intensive Care Med. 2000;26(5):501-7.

Received on 20/03/2014

Accepted for publication 20/05/2014

Conflict of interest: none.

Source of funding: none.

Address for correspondence:

Cíntia Lourenço Santos

E-mail:cintialsvet@gmail.com 